\title{
African Cereal Stem Borers: Economic Importance, Taxonomy, Natural Enemies and Control
}

\author{
Edited by A Polaszek, International Institute of Entomology, UK
}

An assemblage of approximately twenty moth species belonging to the families $\mathrm{Crambidae}$, Pyralidae and Noctuidae constitute the most important cereal pests in many parts of Africa. The caterpillars of these moths bore into the stems of maize, sorghum, millet and rice, often killing the plant, and are commonly known as stem or stalk borers. The cereals attacked are grown by smallholders to feed themselves and their families and are of great importance as the staple food for the population in most parts of Africa. Complex control measures, including the use of chemicals, are often inappropriate.

This book provides fundamental information necessary for formulating integrated pest management of Airican cereal stem borers, in particular any natural enemy component. Firstly, the economically important species are characterized regionally and according to their biology and host plants, both wild and cultivated. The taxonomy of the moths, their larvae and their natural enemies is examined in detail and techniques of rearing are described. Illustrated keys are provided for their recognition, and their distributions and hosts are listed. Finally, the control measures currently in use and those being investigated, are summarized.

This book is essential reading for applied entomologists, agronomists and extension workers with an active interest in cereal production in Africa and will be of value to all those concerned with integrated pest management in the tropics.

\section{Contents:}

Fconomic Importance

- Host Plants

- Maize: West and Central Africa

- Maize and Sorghum: East Africa

- Maize and Grain Sorghum: Southern Africa

- Sorghum: West Africa

- Millet: West Africa

- Rice: West Africa

- Rearing Maize and Sorghum Stem Borers

Taxonomy

- Lepidoptera: Introduction

- Noctuidae

- Pyraloidea: Crambidae, Pyralidae

- Larvale (Morphology)

- Larvae (Electrophoresis)

\section{Natural Enemies}

- Hymenoptera: Introduction

- Hymenoptera: Key to Families

- Bethylidae

- Braconidae

- Ceraphronidae

- Chalcidoidea

- Ichneumonidae

- Scelionidae

- Diptera

- Nematoda, Fungi, Protozoa, Bacteria and Viruses

- Predators

Control

- Integrated Pest Management

- Chemical Control

- Cultural Control

- Biological Control

Glossary

\footnotetext{
May $1998 \quad 592$ pages HB

ISBN () 851991750

66 colour plates

ŁU) $5.00(\mathrm{US} \$ 175.00)$
}

For further information or to order please contact $C A B$ INTERNATIONAL headquarters or an exclusive CAB INTERNATIONAL distributor in your area.

Please add E2.00 per book postage and packing (excluding $U K$ ).

\section{CAB INTERNATIONAL}

Headquarters, Wallingford, Oxon OX10 8DE, UK. Tel: (01491) 832111 Fax: (01491) 833508 E-mail: cabi@cabi.org

North America, 198 Madison Avenue, New York, NY 10016, USA. Tel: 2127266490 Fax: 2126867993 E-mail: cabi-nao@cabi.org Africa, Africa Regional Centre, PO Box 633, Village Market, Nairobi, Kenya. Tel: 2542521450 Fax: 2542521001 E-mail: cabi-roaf@cabi.org

Asia, PO Box 210, 43409 UPM Serdang, Malaysia. Tel: (03) 9432921 Fax: (03) 9436400 E-mail: cabi-aro@cabi.org

Caribbean, Gordon Street, Curepe, Trinidad and Tobago. Tel: 8686457628 Fax: 8686632859 E-mail: cabi-cro@cabi.org 


\title{
Thysanoptera: An Identification Guide, 2nd Edition
}

\author{
L A Mound, CSIRO Entomology, Australia and G Kibby, formerly of the International Institute of \\ Entomology, London, UK
}

A number of species of Thysanoptera (thrips) are increasingly important crop pests in many parts of the world, as well as in some cases being vectors of plant disease. Communicating the known information about a species of organism is dependent on our ability to recognise or identify it accurately. This book is a completely revised and rewritten edition of the standard, widely used manual on these minute flying insects written by J.M. Palmer, L.A. Mound and G.J. du Heaume and published in 1989 as CIE Guides to Insects of Importance to Man 2. Thysanoptera, which provides a practical identification guide on a worldwide scale. The previous version posed problems for students in terms of fluency in English \& knowledge of dichotomous keys. However, this thoroughly updated edition incorporates a new set of pictorial keys, which have been developed and used very successfully for training courses at the International Institute of Entomology and which will greatly enhance the ability of the non-specialist to identify thrips to species.

Individuals of these insects can usually be identified only by examination under a microscope, often at high power. Within each species, individuals can vary in size, colour and shape and their appearance can be altered by techniques used in preparation. This booklet describes techniques used in the preparation of thrip specimens onto slides for identification and the means of identifying slide-mounted specimens most commonly encountered. It also introduces students to the biological diversity that is found amongst the Thysanoptera, their economic importance in terms of both damaging and beneficial effects, new identification techniques, additional information and taxa, glossary of technical terms, notes on each genus (described alphabetically within their families and subfamilies). Supplementary keys to species are also given within four genera that include several pest species (Caliothrips, Frankliniella, Scirtothrips and Thrips) along with new distribution records which have occurred since the publication of the first edition. It is an essential tool for applied entomologists and crop protection specialists involved in the control of crop pest thrips, and thrip taxonomists.

\section{Contents:}

Introduction

Publications About Thrips

Biology

- Biological Diversity

- Life Cycles

- Sex Determination and Sexual Dimorphism

- Dispersal

- Feeding

Economic Importance of Thrips

- Feeding Damage

- Virus Transmission

- Direct Effects

- Beneficial Thrips

Preparatory Techniques for Identifications

Thrips Classification

Thrips Identification

Characters Used in Identifications

Visual Keys to Genera

Figures for Species Keys

\author{
Sub-order Terebrantia \\ - Family Merothripidae \\ - Family Acolothripidae \\ - Family Heterothripidae \\ - Family Adiheterothripidae \\ - Family Thripidae \\ - Sub-family Panchaetothripinae \\ - Sub-family Thripinae \\ Sub-order Tubulifera \\ - Family Phlaeothripidae \\ - Sub-family Idolothripinae \\ - Sub-family Phlaeothripinae \\ Bibliography \\ Glossary \\ Host Plant Index \\ Genera and Species Index
}

July $1998 \quad 70$ pages $\quad$ A4 format $\quad$ Spiral bound

£19.95(US\$35.00)

For further information or to order please contact $C A B$ INTERNATIONAL headquarters or an exclusive CAB INTERNATIONAL distributor in your area. Please add $\$ 2.00$ per book postage and packing (excluding $U K)$.

\section{CAB INTERNATIONAL}

Headquarters, Wallingford, Oxon OX10 8DE, UK. Tel: (01491) 832111 Fax: (01491) 833508 E-mail: cabi@cabi.org

North America, 198 Madison Avenue, New York, NY 10016, USA. Tel: 2127266490 Fax: 2126867993 E-mail: cabi-nao@cabi.org Africa, Africa Regional Centre, PO Box 633, Village Market, Nairobi, Kenya. Tel: 2542521450 Fax: 2542521001 E-mail: cabi-roaf@cabi.org Asia, PO Box 210, 43409 UPM Serdang, Malaysia. Tel: (03) 9432921 Fax: (03) 9436400 E-mail: cabi-aro@cabi.org Caribbean, Gordon Street, Curepe, Trinidad and Tobago. Tel: 8686457628 Fax: 8686632859 E-mail: cabi-cro@cabi.org 


\section{NOTES FOR AUTHORS}

The Bulletin of Entomological Research publishes original research papers, review articles and short communications concerning insects, mites, ticks or other arthropods of economic importance in agriculture, forestry, stored products, biological control, medicine, animal health and natural resource management. The geographical scope of the Bulletin is worldwide. Taxonomic papers are accepted if relevant. The Bulletin is also produced electronically and is available on the WWW to subscribers. The Bulletin also publishes a supplement series.

Page Format. The Journal is printed in a two-column format (column width of $80 \mathrm{~mm}$ ) with a text area of $170 \times 225 \mathrm{~mm}$

Text. Papers should be typed, on one side of the paper only, with double line spacing and ample margins (at least $1.5 \mathrm{~cm}$ ) on each side and with no underlining or bold in text except for scientific names. Draft quality print from a word-processor is not acceptable. Standard abbreviations (e.g. fig. and figs) and metric units must be used. Use British rather than American spellings. Use ' $z$ ' rather than 's' spellings in words with 'ize'.

Disks. Upon acceptance, authors are requested to submit a computer disk containing the final version of their paper along with the final manuscript to the editorial office. Please do the following: (1) Label disk clearly with author's name, title of journal and short title of the article; (2) Specify which word processing software (including which version) was used (e.g. WordPerfect 6.0); (3) Specify what computer was used; (4) Include both original file and ASCII file on the disk; (5) Keep a backup disk for reference and safety.

Abstract. Each paper must commence with an accurate, informative abstract in one paragraph, that is complete in itself and intelligible without reference to text or figures. It should not exceed 250 words. A short title should be provided as a running head.

Tables. Tables should be reduced to the simplest form and present only essential data. They should be submitted on separate sheets at the end of the article and must fit into single column, full width or landscape (if absolutely necessary) format. Captions should be typed on a separate sheet. The use of vertical rules should be avoided.

Illustrations. Copies of artwork only should be submitted. The original illustrations should accompany the paper after acceptance and revision. Captions should be typed on a separate sheet.

Line drawings

These should be sharp and clear, black ink on white paper to about 1.5 times the intended final size. The lettering and lines should be of sufficient thickness and quality to stand reduction. Computer generated figures and graphs should not contain grey tints or complicated hatching

Half-tone photographs

Black and white half-tone photographs are acceptable where they are a real contribution to the text. They should be prints of good quality at the intended final size with any required lettering or numbering inserted by the author.

Voucher specimens. The deposition of voucher specimens should be considered where appropriate.
References. References must be based on the name and year system, give full journal titles and conform to the following styles:

Follett, P.A. \& Roderick, G.K. (1996) Genetic estimates of dispersal ability in the leucaena psyllid predator Curinus coeruleus (Coleoptera: Coccinellidae): implications for biological control. Bulletin of Entomological Research 86, 355-361.

Nevill, E.M., Kappmeier, K. \& Venter, G.J. (1993) Tsetse fly research in Zululand. in Proceedings of the ninth Entomological Congress organized by the Entomological Society of Southern Africa, Johannesburg, 28 June-1 July 1993 Pretoria, Entomological Society of South Africa, p. 81.

Wilson, M.D. \& Post, R.J. (1994) Integration of morphometric, cytogenetic and molecular techniques: A case study of Simulium damnosum. pp. 215-224 in Hawksworth, D.L. (Ed.) The identification and characterization of pest organisms. Wallingford, CAB INTERNATIONAL

Citation of authors in the text should appear in the form: Polaszek (1996) or (Polaszek, 1996). Authors should be cited in chronological order as: (Blackman et al., 1994; Roberts \& Kumar, 1995).

Proofs. Authors will receive two sets of page proofs. One set is for correcting and should be returned as promptly as possible to the address given, the other set is to be retained.

Voucher copy. A voucher copy of the Journal is provided free to the author (or major author) of each paper.

Offprints. 50 copies of each paper are provided free to the author (or major author) of each paper. Additional copies may be obtained on payment and the number required must be specified and ordered at proof stage, when prices will be quoted. Orders must be received before the issue has gone to press.

Copyright. Authors will be supplied with a copyright form which must be completed and returned to the Publisher. Papers are accepted on the understanding that the work has been submitted exclusively to the Journal and has not been previously published elsewhere unless otherwise stated.

Disposal of material. Once published, all copies of the manuscript, correspondence and artwork will be held for six months before disposal. Authors must contact the Editor if they wish to have any material returned.

Manuscripts. Three copies of the manuscript and artwork should be submitted to:

Editor-in-Chief, Bulletin of Entomological Research, International Institute of Entomology, 56 Queen's Gate, London, SW7 5JR, UK. 


\section{Bulletin of Entomological Research}

Booth, R.G. A review of the species resembling Chilocorus nigrita (Coleoptera: Coccinellidae): potential agents for biological control

Colvin, J., Fishpool, L.D.C., Fargette, D., Sherington, J. \& Fauquet, C. Bemisia tabaci (Hemiptera: Aleyrodidae) trap catches in a cassava field in Côte d'Ivoire in relation to environmental factors and the distribution of African cassava mosaic disease

Cumming, G.S. Host preference in African ticks (Acari: Ixodida): a quantitative data set.

Edwards, P.B. Seasonal abundance and parasitism of Mesoclanis seed flies (Diptera: Tephritidae) in South Africa, and implications for the biological control of Chrysanthemoides monilifera (Asteraceae) in Australia

Goldson, S.L., Proffitt, J.R. \& Baird, D.B. The bionomics of Listronotus bonariensis (Coleoptera: Curculionidae) in Canterbury, New Zealand

Hargrove, J.W. \& Williams, B.G. Optimized simulation as an aid to modelling, with an application to the study of a population of tsetse flies, Glossina morsitans morsitans (Diptera: Glossinidae).

Horowitz, A.R., Mendelson, Z., Weintraub, P.G. \& Ishaaya, I. Comparative toxicity of foliar and systemic applications of acetamiprid and imidacloprid against the cotton whitefly, Bemisia tabaci (Hemiptera: Aleyrodidae)

Matthiessen, J.N. \& Learmonth, S.E. Seasonally contrasting activity of African black beetle, Heteronychus arator (Coleoptera: Scarabaeidae): implications for populations, pest status and management.

Shah, P.A., Godonou, I., Gbongboui, C., Hossou, A. \& Lomer, C.J. Survival and mortality of grasshopper egg pods in semi-arid cereal cropping areas of northern Benin

Ueno, T. Selective host-feeding on parasitized hosts by the parasitoid Itoplectis naranyae (Hymenoptera: Ichneumonidae) and its implication for biological control

Way, M.J., Islam, Z., Heong, K.L. \& Joshi, R.C. Ants in tropical irrigated rice: distribution and abundance, especially of Solenopsis geminata (Hymenoptera: Formicidae).

Wilson, L.J., Bauer, L.R. \& Lally, D.A. Effect of early season insecticide use on predators and outbreaks of spider mites (Acari: Tetranychidae) in cotton

Book Reviews without prior permission of the copyright owner. 